\title{
CZY MENDELSON BY COŚ NIE OBMYŚLIE? - GENEZA POLSKIEJ PARTII SOCJALISTYCZNEJ ZABORU PRUSKIEGO W ŚWIETLE KONTAKTÓW Z GRUPĄ LONDYNSSKĄ
}

Streszczenie. Artykuł podejmuje próbę zdefiniowania relacji między dwoma polskimi ośrodkami socjalistycznymi - londyńskim, skupionym wokół Stanisława Mendelsona, oraz berlińskim, z którego wyrosła Polska Partia Socjalistyczna zaboru pruskiego. Tłem dla badań jest polemika z zastaną historiografią. Na podstawie archiwaliów oraz wspomnień podjęta została próba odtworzenia związków między oboma ugrupowaniami. Analiza materiału źródłowego wskazuje na istnienie relacji o charakterze finansowym, personalnym oraz ideowym, które to czynniki sugerują rzeczywistą zależność socjalistów berlińskich od otoczenia Mendelsona.

Słowa kluczowe: „Gazeta Robotnicza”, Stanisław Grabski, Witold Jodko Narkiewicz, Stanisław Mendelson, PPS, PPSzp, socjalizm, SPD, Towarzystwo Socjalistów Polskich, ZZSP.

\section{Wstęp}

$\mathrm{P}$ olska historiografia po 1945 r. obficie opisywała dzieje polskiego ruchu robotniczego. Trend ten minął po $1989 \mathrm{r}$. Wiele zagadnień opracowanych lub ledwie napoczętych w tamtym okresie zasługuje na ponowne rozważenie. Jednym z takich zagadnień jest geneza Polskiej Partii Socjalistycznej zaboru pruskiego (dalej: PPSzp). Moim celem było opracowanie i analiza źródeł dotyczących powstania tej partii, ze szczególnym uwzględnieniem kontaktów działaczy polskich na ziemiach niemieckich z zagranicą, w tym z grupą skupioną wokół Stanisława Mendelsona. 
Dotychczasowy dorobek polskiej nauki w tym zakresie nie jest mały. Jednakże, zacząć trzeba od sprecyzowania pojęcia kluczowego dla niniejszej pracy. Nasza historiografia objęła jak dotąd szereg zagadnień, co zostało już wspomniane, z zakresu dziejów polskiego ruchu robotniczego. Wyrażenie to sugeruje, że robotnicy byli główną siłą sprawczą, że ruch tak naprawdę im zawdzięcza swoją żywotność. Idealistyczne to założenie niestety mija się z prawdą, o czym świadczą wielorakie źródła. Zdarzało się, że robotnicy zaangażowani w pracę partyjną nie mieli pojęcia, czym jest socjalizm ${ }^{1}$. Lepszym określeniem jest ruch socjalistyczny, słowo wolne od zabarwienia ideologicznego, będące zdatnym do ogarnięcia przedstawicieli różnych klas społecznych, połączonych wspólną ideą. Tym określeniem będę posługiwał się w niniejszej pracy. Jego użycie ma przede wszystkim wyraźnie podkreślić odcięcie się od metodologii marksistowskiej, popularnej w literaturze opracowującej zagadnienie socjalizmu.

Powstanie partii socjalistycznej nie mogło przejść bez echa w dorobku historyków PRL. W poniższym zestawieniu uwzględniłem pozycje związane z realiami politycznymi, religijnymi i społecznymi mającymi szczególny wpływ na rozwój ruchu socjalistycznego, a także te związane bezpośrednio z PPSzp lub Towarzystwem Socjalistów Polskich (dalej: TSP) - głównym organizacyjnym poprzednikiem PPSzp. Emanacją aktywności tegoż Towarzystwa było wydawanie „Gazety Robotniczej” - także opracowania jej dotyczące zostały wykorzystane.

Sztandarową pozycją dotyczącą tej tematyki jest monografia Władysława Zielińskiego, opisująca szczegółowo genezę PPSzp². Prezentuje ona szereg zagadnień organizacyjnych, główne założenia ideologiczne działaczy, niektóre akcje podejmowane w przededniu zawiązania partii. Autor oszczędnie wypowiada się o kontaktach działaczy lokalnych z zagranicą, tematowi temu poświęcając niewiele miejsca, niemniej to ta praca pozostaje najbardziej wartościowym opracowaniem przedmiotu. Niektóre tezy monografii Zielińskiego są rozwinięciem jego monumentalnej, wydanej rok wcześniej, pracy o PPSzp ${ }^{3}$.

Opisaniu działań prowadzonych na łamach „Gazety Robotniczej” najbardziej przysłużyły się prace Jerzego Myślińskiego ${ }^{4}$. Artykuły i monografie tego

${ }^{1}$ Archiwum Akt Nowych [dalej: AAN], Archiwum Londyńskie Polskiej Partii Socjalistycznej [dalej: AL PPS], 305/VII/630 List Władysława Kurowskiego, 25.05.1891, t. 24, k. 1.

2 W. Zieliński, Geneza i powstanie Polskiej Partii Socjalistycznej zaboru pruskiego, Katowice 1979.

${ }^{3}$ Idem, Polska Partia Socjalistyczna zaboru pruskiego 1890/1893-1914, Katowice 1978.

${ }^{4}$ J. Myśliński, Polska prasa socjalistyczna w okresie zaborów, Warszawa 1982, s. 100-121; idem, Model socjalistycznego periodyku dla robotników w okresie zaborów, [w:] Wokół tradycji kultury robotniczej w Polsce, red. A. Żarnowska, Warszawa 1986, s. 373-405. 
autora wnoszą wiele do badań nad prasą socjalistyczną omawianego okresu. Myśliński jako bodaj jedyny określił agitację jako główny element działalności socjalistów polskich w Niemczech ${ }^{5}$. Co więcej, nazwał ich gazetę najbardziej dostosowanym do robotniczego odbiorcy pismem socjalistycznym na ziemiach polskich ${ }^{6}$. Prace Myślińskiego opisują istotny element genezy PPSzp - działalność agitacyjną i propagandową organizacji ją poprzedzających.

Samej „Gazecie Robotniczej” poświęcili artykuły Joachim Glensk ${ }^{7}$ i Stanisław Łuczko $^{8}$. Są one interesujące ze względu na zakres tematyczny, jaki obejmują. Praca Glenska wyczerpuje zagadnienie prześladowania redaktorów i współpracowników pisma przez organy państwowe. Artykuł Stanisława Łuczki natomiast wnikliwie bada propagandowe zastosowanie wierszy publikowanych na łamach gazety. Obie prace pełnią de facto funkcję uzupełniającą względem dorobku Myślińskiego.

Innym czynnikiem mającym wpływ na genezę PPSzp jest tożsamość narodowa. Kwestia obywateli niemieckich polskiej narodowości również została poruszona w literaturze przedmiotu. Czynnikiem, który w warunkach niemieckich łączył się nierozerwalnie z narodowością polską, była przynależność do łona Kościoła katolickiego. 0 kwestii narodowej najbardziej radykalnie wypowiedział się bodaj Władysław Zieliński, nazywając ją czynnikiem dynamizującym ${ }^{9}$. Zależności między wyznaniem, narodowością, a preferencjami politycznymi Polaków w Niemczech, w tym pod zaborem pruskim, rozważał także Jerzy Myśliński, analizując drobiazgowo warunki rozwoju ruchu socjalistycznego na ziemiach polskich ${ }^{10}$. Dalej poszedł Janusz Żarnowski, opisując relacje między Kościołem a robotnikami, zaznaczając także potężną pozycję Kościoła wśród Polaków w Niemczech - wynik Kulturkampfu ${ }^{11}$. Uwarunkowania polityczne, w tym narodowościowe, bytu robotniczego wpływały również na program budowy państwa socjalistycznego ${ }^{12}$, co poszerza horyzont rozważań autora o kwestie ideologiczne.

${ }^{5}$ Idem, Model socjalistycznego periodyku dla robotników w okresie zaborów, [w:] Wokót tradycji kultury robotniczej w Polsce, red. A. Żarnowska, Warszawa 1986, s. 374-375, 398.

${ }^{6}$ Ibidem, s. 398.

7 J. Glensk, Procesy prasowe „Gazety Robotniczej” w latach 1891-1901, [w:] Klasa robotnicza na Śląsku, t. 5, red. F. Hawranek, Opole 1980, s. 201-234.

8 S.Ł. Łuczko, Poezja na łamach „Gazety Robotniczej” 1891-1901, [w:] Klasa robotnicza na Śląsku, t. 5, red. F. Hawranek, Opole 1980, s. 235-272.

9 W. Zieliński, Rola klasy robotniczej i ruchu robotniczego $w$ walce o wyzwolenie narodowe, [w:] 100-lecie polskiego ruchu robotniczego. Odczyty, Katowice 1982, s. 11.

${ }^{10}$ J. Myśliński, Swobody, fabryk i ziemi! Poczq̨tki polskiego ruchu robotniczego pod zaborami, [w:] Ruch robotniczy na ziemiach polskich, red. S. Sierpowski, Warszawa 2002, s. 16-21.

11 J. Żarnowski, Robotnicy polscy a Kościół katolicki, [w:] Wokół tradycji kultury robotniczej w Polsce, red. A. Żarnowska, Warszawa 1986, s. 273-293.

12 J. Przewłocki, Kształtowanie się wizji socjalistycznej państwowości w programach i działaniu polskiego ruchu robotniczego, [w:] 100-lecie polskiego..., s. 6. 
Istnieje również kilka bardzo interesujących prac, które podchodzą do zagadnienia początków partii socjalistycznych z zupełnie innej strony. Genezy PPSzp upatrują one w walce klasowej. W nurt ten wpisuje się artykuł Mariana Łabuza ${ }^{13}$, który agitację klasyfikuje jako formę walki, wpływającą na postawy robotników, a postawy te determinowały - jak zweryfikowały kolejne dziesięciolecia - popularność ruchu reformistycznego ${ }^{14}$. Absolutnie oryginalną pracą jest artykuł Edwarda Pietraszka o etosie robotniczym ${ }^{15}$. Autor opisał wzorzec zachowań, którym cechuje się robotnik. Co interesujące, podkreślono także przywiązanie robotnika polskiego na ziemiach niemieckich, nie tylko w zaborze pruskim, do Kościoła ${ }^{16}$. Praca ta porusza problemy narodowościowe i religijne, które wpływały na sytuację Polaków w Niemczech na przełomie XIX i XX w.

Tak prezentuje się literatura dotycząca tematu niniejszego artykułu lub kwestii dla tegoż istotnych - nie jest to oczywiście lista kompletna, choć dobrze oddaje ducha dotychczasowej historiografii. Z powyższego spisu wyciągnąć można następujące wnioski: prace te poszukują przyczyn funkcjonowania ruchu socjalistycznego oraz liderów tego ruchu w środowisku robotniczym. Tendencja ta przejawia się także we wspomnieniach spisanych po $1945 \mathrm{r}^{17}$ - pełnią one funkcję falsyfikującą stan rzeczywisty. Obecność i zaangażowanie robotników stanowiło oczywiście conditio sine qua non tworzenia się zalążków partii socjalistycznych - nie oni jednak trzymali stery i nie oni byli siłą napędową organizowania się socjalistów, ich istnienie było warunkiem koniecznym, ale nie wystarczającym.

Marginalizowane są działania inteligencji emigracyjnej, tak samo jak marginalizowane są kontakty działaczy miejscowych z zagranicą w ogóle. Dlatego też wiele uwagi zamierzam poświęcić kontaktom z ośrodkiem londyńskim skupionym wokół Stanisława Mendelsona. Z tego ośrodka wyrósł w niedługim czasie Związek Zagraniczny Socjalistów Polskich (dalej: ZZSP). Niniejsza praca nie ma na celu opisania tej historii na nowo - leży to poza jej obrębem tematycznym. Jednakże, przez zwrócenie uwagi na dotychczas umniejszane elementy może zmienić sposób myślenia o początkach polskiego ruchu socjalistycznego na ziemiach niemieckich, przesunąć akcenty.

13 M. Łabuz, Polski ruch robotniczy w walce o postęp społeczny /1878-1939/, [w:] 100-lecie polskiego ruchu robotniczego. Odczyty, Katowice 1982.

${ }^{14}$ Ibidem, s. 4-8.

15 E. Pietraszek, Etos robotniczy na przełomie epok (1890-1918), [w:] Robotnicy polscy a Kościół katolicki, [w:] Wokół tradycji kultury robotniczej w Polsce, red. A. Żarnowska, Warszawa 1986, s. 142-173.

${ }^{16}$ Ibidem, s. 167.

${ }^{17}$ AAN, Zbiór akt osobowych działaczy ruchu robotniczego [dalej: Zbiór akt], 10946, Życiorys Franciszka Morawskiego; także: AAN, Zbiór akt, 14315, Życiorys Marii Jankowskiej-Mendelson. 


\section{Podstawa źródłowa}

Podstawę źródłową stanowią zachowane listy prominentnych działaczy TSP oraz ludzi zaangażowanych w proces wydawniczy „Gazety Robotniczej”, a także niektórych przedstawicieli grupy londyńskiej. Analizowane były listy następujących socjalistów polskich: Władysława Kurowskiego, Franciszka Morawskiego, Stanisława Grabskiego, Ignacego Daszyńskiego, Stanisława Przybyszewskiego, Stanisława Mendelsona. Wzajemna wymiana myśli między dwoma ośrodkami: londyńskim, skupionym wokół Mendelsona, oraz berlińskim, wykazuje nierówną pozycję, a momentami nawet zależność ośrodka berlińskiego. Tę właśnie zależność ma na celu opisać niniejsza praca.

Analizie podlegały również spisane i wydane wspomnienia Ignacego Daszyńskiego ${ }^{18}$, Stanisława Grabskiego ${ }^{19}$ oraz Stanisława Przybyszewskiego ${ }^{20}$ - kolejnych redaktorów „Gazety Robotniczej”, wokół której skupiała się oś działalności TSP. Redaktorzy stanowili istotny element w funkcjonowaniu ośrodka berlińskiego, byli to ludzie często namaszczeni przez polskich socjalistów na emigracji ${ }^{21}$, którzy istotnie wpływali na kształtowanie się oblicza ideowego ugrupowania ${ }^{22}$.

Kryterium doboru materiałów stanowiła bliskość działacza z berlińskimi socjalistami, zaangażowanie $\mathrm{w}$ pracę polityczną, a także późniejsze losy. Redaktorzy Gazety - Daszyński oraz Grabski - kontynuowali swoje kariery polityczne w II RP. Materiał pomocniczy stanowiła niekiedy sama Gazeta, będąca wyrazicielką poglądów TSP i osób za nim stojących.

Szczególną uwagą otoczona została wzajemna korespondencja liderów obu grup - Morawskiego i Mendelsona. To właśnie z obserwacji tej relacji wywodzę tezę o podporządkowaniu moralnym, finansowym i personalnym - choć nie organizacyjnym - ośrodka berlińskiego.

\section{Początek współpracy grup londyńskiej i berlińskiej}

Polski ruch socjalistyczny na ziemiach niemieckich rozpoczął swoją aktywność przed 1 października $1890 \mathrm{r}^{23}$, niemniej dopiero po zniesieniu ustaw wyjątkowych przeciwko socjalistom mógł w pełni rozwinąć skrzydła. Naturalnym sprzymierzeńcem dla polskich socjalistów była wzorowo urządzona i liczna Socjaldemokratyczna Partia Niemiec (dalej: SPD). Kwestia korzyści

18 I. Daszyński, Pamiętniki, red. P. Dembowski, Warszawa 2016.

19 S. Grabski, Pamiętniki, t. 1, red. W. Stankiewicz, Warszawa 1989.

20 S. Przybyszewski, Moi współcześni, red. J. Bartnicka, Warszawa 1959.

${ }^{21}$ AAN, AL PPS, 305/VII/630, Morawski do Mendelsona, 7.05.1891, t. 29, k. 172.

${ }^{22}$ S. Grabski, Pamiętniki, t. I, red. W. Stankiewicz, Warszawa 1989, s. 77.

${ }^{23}$ AAN, Zbiór akt. 10946, Życiorys Franciszka Morawskiego, k. 1. 
jakie odniosła ze współpracy z rodzącym się polskim ugrupowaniem została już w literaturze omówiona ${ }^{24}$, tutaj jedynie przytoczę ten pogląd - SPD zyskiwała działaczy uwierzytelniających jej działania w środowisku polskim, piszących po polsku. Z drugiej strony - polscy socjaliści otrzymali potrzebne im do funkcjonowania wsparcie organizacyjne i finansowe od socjalistów niemieckich.

Bardzo szybko po zniesieniu ustaw wyjątkowych, a mianowicie 12 grudnia 1890 r., założono TSP ${ }^{25}$. Było ono organizacyjnie niezależne od władz SPD. Wyrazem działalności towarzystwa stało się wydawanie „Gazety Robotniczej". Podstawą jej funkcjonowania była uchwała zjazdu partyjnego SPD w Halle ${ }^{26}$. Gazeta od początku dotowana była przez niemieckich socjaldemokratów. Już w styczniu 1891 r. SPD wsparło Gazetę sumą 175 marek $^{27}$. Niewydolni finansowo polscy socjaliści w Berlinie zdawali sobie sprawę z własnej słabości oraz z potrzeby znalezienia przywódcy moralnego ${ }^{28}$, czego wyrazem była próba nawiązania kontaktu ze Stanisławem Mendelsonem. Obawy te oraz chęć nawiązania współpracy wyraził Franciszek Morawski ${ }^{29}$. Prosił on Mendelsona o materiały duchowne ${ }^{30}$ dla wspomożenia pracy TSP. Tak rozpoczęła się współpraca ośrodków berlińskiego i londyńskiego.

Zacieśnienie tej współpracy nastąpiło w pierwszym kwartale $1891 \mathrm{r}$. Dokładna datacja jest tutaj dyskusyjna. Jeden z zastanych poglądów wskazuje, że pierwszym krokiem zmierzającym do podporządkowania ośrodka berlińskiego było powstanie Komitetu Prasowo-Agitacyjnego w dniu 3 marca $1891 \mathrm{r}^{31}$ Natomiast, już w styczniu ${ }^{32}$ do Berlina przybył Wincenty Sikorski, przyjaciel i wieloletni współpracownik Mendelsona ${ }^{33}$. Jego obecność stanowi dowód zaangażowania grupy londyńskiej w działania w Berlinie jeszcze przed powstaniem Komitetu. Od stycznia do sierpnia $1891 \mathrm{r}$. Sikorski odgrywał rolę łącznika pomiędzy socjalistami polskimi w Berlinie a Mendelsonem, toteż data jego przybycia może zostać uznana za umowną datę nawiązania współpracy.

${ }^{24}$ V.W. Zieliński, Geneza..., s. 45-47.

25 „Gazeta Robotnicza” 3.01.1891, R. I, nr 1, s. 4.

${ }^{26}$ Ibidem, s. 1.

${ }^{27}$ Ibidem, nr 42, s. 1.

${ }^{28}$ AAN, 305/VII/630, AL PPS, List Morawskiego, Berlin 16.05.1893, t. 29 - na odwrocie listu znajduje się pytanie zawarte w tytule tej pracy: Czy Mendelson by coś nie obmyślił?

${ }^{29}$ AAN, AL PPS, 305/VII/630, Morawski do socjalisty w Paryżu, 6.12.1890, t. 29, k. 163.

${ }^{30}$ Ibidem.

31 V.W. Zieliński, Geneza..., s. 50.

32 A. Pacholczykowa, Wincenty Sikorski, [w:] Polski Słownik Biograficzny [dalej: PSB], t. 37, Warszawa-Kraków 1996-1997, s. 464-468.

${ }^{33}$ AAN, AL PPS, sygn. 305/VII/630, Mendelson do Sikorskiego, 1.09.1892, t. 27, k. 579. 
Co do korzyści płynących ze współpracy z ośrodkiem berlińskim dla Mendelsona, było ich przynajmniej kilka. Niewątpliwie miał on wielkie ambicje i plany. Jego listy dowodzą ponadprzeciętnych zdolności organizacyjnych i uporządkowania myśli. Jednocześnie narzucał swoje zdanie, nie znosił sprzeciwu i potrafił przenieść animozje osobiste na grunt polityczny ${ }^{34}$. Schlebiająca Mendelsonowi prośba o pomoc ze strony działaczy berlińskich mogła wpłynąć na jego decyzję o wsparciu finansowym i personalnym dla tego środowiska. Nie była to jednak decyzja bezinteresowna. Kontrola nad posunięciami ośrodka berlińskiego miała wpływ na kontakty z SPD ${ }^{35}$ - najlepiej bodaj zorganizowaną partią socjalistyczną Europy - a był to czas jeszcze sprzed przyjęcia programu socjalistyczno-patriotycznego ${ }^{36}$ i zróżnicowania się programów internacjonalistycznego i niepodległościowego. Kontakty z niemieckimi socjalistami były pożądane i przydatne dla polskich socjalistów. Dopiero po opowiedzeniu się za niepodległością Polski, co nastąpiło w 1892 r., konflikt z SPD stał się nieunikniony - uznanie polskich dążeń oznaczałoby poparcie dla terytorialnego zmniejszenia Niemiec. Dla strony polskiej, dalsza współpraca z SPD również nie niosła aż tylu korzyści - tylko oddzielne struktury organizacyjne mogły nadać ruchowi swoisty, polski charakter i go uwierzytelnić w oczach rodzimych robotników. Inną jeszcze korzyścią dla grupy Mendelsona, którą uzyskał za pośrednictwem socjalistów polskich w Berlinie, była ich działalność wśród polskiej ludności na terenie Niemiec. Mogła ona stanowić przedłużenie ideowe grupy Mendelsona. Działacze berlińscy agitowali zgodnie z londyńskimi zaleceniami, poszerzając w kraju wpływy grupy londyńskiej.

Pierwsze problemy pojawiły się $\mathrm{w}$ ciągu kilku miesięcy. W kwietniu 1891 r. Sikorski zaczął być nękany przez policję ${ }^{37}$. W tej sytuacji Mendelson starał się zabezpieczyć przed utratą wpływu na TSP i redakcję Gazety. Końcem kwietnia poprosił Morawskiego o zorientowanie się, czy zarząd SPD nie zgodziłby się na ustanowienie Daszyńskiego redaktorem „Gazety Robotniczej”38. Myśląc o możliwości aresztowania Sikorskiego przez policję, Mendelson zabiegał o oddanie redakcji znanej sobie osobie. W ten sposób agitacja prowadzona przez Gazetę nie była co prawda ściśle kontrolowana przez emigrantów, niemniej spoczywała w zaufanych rękach. W sierpniu Sikorski

${ }^{34}$ AAN, AL PPS, 305/VII/630, Mendelson do współpracowników, 27.06.1892, t. 27, k. 573.

35 I. Daszyński, Pamiętniki, red. P. Dembowski, Warszawa 2016, s. 96.

${ }^{36}$ AAN, Zbiór akt, 7887. Autobiografia S. Grabskiego.

37 A. Pacholczykowa, op. cit., s. 465.

${ }^{38}$ AAN, AL PPS, sygn. 305/VII/630, Morawski do Mendelsona, 7.05.1891, t. 29, k. 172. 
został wydalony z Berlina ${ }^{39}$, a we wrześniu redakcję objął Daszyński ${ }^{40}$. W ten sposób zachowana została trwałość kontaktów między oboma ośrodkami.

We wrześniu Morawski wysłał do Mendelsona niezwykle ciekawy list ${ }^{41}$. Wynika z niego, że Mendelson zaproponował zlanie się „Przedświtu” i „Gazety Robotniczej" w jedno pismo, na co Morawski się zgodził, pod warunkiem że pismo wychodziłoby w Berlinie lub Poznaniu ${ }^{42}$. Koncepcja ta nie była pozbawiona racjonalnych podstaw. „Gazecie Robotniczej” brakowało wykwalifikowanych autorów i redaktorów. „Przedświt” z kolei wychodził z dala od kraju, niewiele mając wspólnego z rzeczywistością otaczającą socjalistów na ziemiach polskich. Pod tymi względami pisma te uzupełniały się. Nieprawdą jest ${ }^{43}$, że łącząc pisma, grupa Mendelsona straciłaby pismo o znacznej już renomie - jednocześnie pismo przez nich współtworzone mogłoby być legalnie wydawane w Niemczech przez działaczy berlińskich ${ }^{44}$. Istniały jednak czynniki, z powodu których koncepcja została odrzucona. Po pierwsze, wydawanie pisma za pośrednictwem ośrodka berlińskiego pozbawiłoby grupę londyńską dominującej pozycji, a jednocześnie uzależniło jej poczynania od SPD, które czuwało nad Gazetą ${ }^{45}$. Po drugie, charakter obu pism był całkowicie odmienny. „Przedświt” był pismem teoretyczno-naukowym, Gazeta zaś trafiać miała przede wszystkim do robotnika, była pismem agitacyjno-propagandowym. Różnicy tej nie dałoby się pogodzić, tym bardziej uwzględniając pogląd Morawskiego, że ludek tutejszy nie jest do czytania przyzwyczajony, a jeżeli coś czyta, to tylko urywkowo, krótkie ustępy ${ }^{46}$. Koncepcja ta zatem, choć ciekawa i dobrze oddająca próby podporządkowania ośrodka berlińskiego, nie mogła zostać w ówczesnych warunkach zrealizowana.

Powyżej opisane działania oraz koncepcje obrazują początki współpracy Mendelsona z socjalistami polskimi w Berlinie. Zarówno szybkie pojawienie się wysłannika grupy londyńskiej, jak i propozycja ustanowienia Daszyńskiego redaktorem, świadczą o zaangażowaniu personalnym otoczenia Men-

39 A. Pacholczykowa, op. cit., s. 465.

40 I. Daszyński, op. cit., s. 38.

${ }^{41}$ AAN, AL PPS, 305/VII/630, Morawski do Mendelsona, 10.09.1891, t. 29, k. 181-184.

42 Ibidem, k. 183.

43 „Przedświt”, zakładając realizację opisywanej koncepcji, zasadniczo przetrwałby pod postacią nowego pisma. Socjaliści w owym okresie stanowili grupę na tyle zmotywowaną, że zmiana tytułu czasopisma nie stanowiłaby czynnika przesądzającego o spadku liczby czytelników.

${ }^{44}$ W. Zieliński, Geneza..., s. 54.

${ }^{45}$ I. Daszyński, op. cit., s. 96 - „Vorwärts” i „Gazeta Robotnicza” drukowane były w tej samej drukarni.

${ }^{46}$ AAN, AL PPS, 305/VII/630, Morawski do Mendelsona, Berlin 16.04.1891, t. 29, k. 169. 
delsona. Koncepcja zlania dwóch gazet o odmiennej grupie docelowej jest przykładem efemerycznej idei, która nie doczekała się realizacji ze względu na realia, a która świadczy o planach zbliżenia ośrodków.

\section{Zależność finansowa}

Kolejnym zagadnieniem jest kondycja finansowa Gazety. Była ona emanacją działalności socjalistów polskich na ziemiach niemieckich, a zatem jej utrzymanie było kluczowe. Przyjrzenie się tej kwestii wyjaśnia, dlaczego w zamian za pomoc finansową Morawski godził się na narzucanie rozwiązań personalnych przez grupę londyńską. Kłopoty finansowe były codziennością Gazety, a jej nieopłacalność - jedną z głównych przyczyn poszukiwania wsparcia. Zarzucenie jej redakcji było jednocześnie niemożliwe, gdyż sens działalności socjalistów - dotarcie do mas i edukacja ich w duchu socjalistycznym - ulotniłby się.

Tygodnik ten założyła niemiecka partia socjalno-demokratyczna i to było jego nieszczęściem. Gdyby takie pismo założyli byli sami Polacy, musiałoby albo upaść z braku pieniędzy, albo rozrosłoby się silnie i miało licznych odbiorców. W niemieckich zaś rękach ani żyć, ani umrzeć nie mogło; miało zawsze za mało abonentów (za mojej redakcji 1300), ale Niemcy pokrywali deficyty - i żyło ${ }^{47}$.

Tak opisywał początki pisma Ignacy Daszyński. Można wyciągnąć z tego wniosek, że dalsza działalność w Niemczech powinna koncentrować się na uniezależnieniu od SPD, jeśli ruch miał się rozwinąć ${ }^{48}$. Wnioskowanie to wydaje się nie uwzględniać realiów ruchu. W okresie przed przyjęciem programu niepodległościowego, współpraca z SPD nie tylko była zyskowną, ale także stanowiła jedyne logiczne rozwiązanie. Co prawda w jednym z listów Morawskiego zachowała się aluzja do przejęcia pisma w polskie ręce ${ }^{49}$, pomysł ten jednak był mrzonką - nie ma po nim śladu w późniejszych źródłach. Przed połową 1892 r. według większości polskich socjalistów nie było potrzeby tworzenia odrębnej polskiej organizacji ${ }^{50}$.

Kwestią poruszoną przez Daszyńskiego we wspomnieniach są deficyty pisma. SPD pokrywało początkowo całe zadłużenie Gazety i umożliwiało mu egzystencję $e^{51}$. Z problemów finansowych dobrze zdawano sobie sprawę

47 I. Daszyński, op. cit., s. 38.

${ }^{48}$ Por. W. Zieliński, Geneza..., s. 66.

49 AAN, AL PPS, 305/VII/630, Morawski do Mendelsona, 10.09.1891, t. 29, k. 183.

${ }^{50}$ AAN AL PPS, 305/VII/630, Morawski do ZZSP, 18.09.1893, t. 29, k. 263.

51 Szczegółowe sprawozdanie z wydatków SPD, [w:] „Gazeta Robotnicza” 17 X 1891, R. I, nr 42, s. 1. 
w redakcji. Morawski już w kwietniu alarmował, że Gazecie grozi upadek z powodu braku prenumeratorów ${ }^{52}$. W lipcu Władysław Kurowski wyliczył, że sprzedając cały nakład, Gazeta ma szansę kwartalnie zarobić 300 marek - czyli tyle, ile miesięcznie kosztowało opłacenie zecera i redakcji ${ }^{53}$. Liczba abonentów rzeczywiście wyglądała tragicznie. Po 7 kwartałach było ich niespełna $300^{54}$, po dwóch latach Mendelson podliczył, że każdy prenumerator kosztuje około tysiąca marek ${ }^{55}$. Mało tego, zarówno ekspedycje Gazety, jak i jej abonenci częstokroć zalegali z opłatami ${ }^{56}$. Z powodu narastających zatorów płatniczych TSP musiało szukać pomocy, by pismo utrzymać.

Jakie były powody aż takich problemów „Gazety Robotniczej”? Zastanawiali się nad nimi i sami działacze, wskazując na niezgodę socjalistów w kraju i na emigracji oraz na niedołężność zarządu pisma ${ }^{57}$. Istniały jednak także i obiektywne powody. Robotnik polski w Niemczech był przywiązany bardziej do swojej narodowości niż klasy ${ }^{58}$. Lata Kulturkampfu wykształciły w nim przeświadczenie, że musi bronić swoich interesów, a wyrazicielem tych interesów został Kościół i posiadacze ziemscy. Niemiec był uważany za wroga, w tym robotnik niemiecki - a w tej sytuacji socjaliści polscy współpracujący z partią niemiecką znajdowali się w położeniu co najmniej trudnym. Istniała myśl o oderwaniu się od SPD, niemniej była to koncepcja nierealna. Współpraca z grupą londyńską dawała możliwość choć częściowego uniezależnienia się od socjaldemokratów niemieckich, choć w ten sposób zezwolono na ingerencje socjalistów polskich na emigracji w sprawy berlińskie.

\section{Sprawy personalne a kontakty między ośrodkami}

W czerwcu 1892 r. zawarto umowę między Mendelsonem z jednej, a Morawskim i Grabskim z drugiej strony ${ }^{59}$. Mendelson osobiście zobowiązał się do pokrywania około połowy miesięcznego deficytu pisma - 175 marek - w zamian otrzymując miejsce w administracji pisma dla swojego współpracownika - Bolesława Antoniego Jędrzejowskiego, ukrywającego się pod pseudonimem Antoni Radecke ${ }^{60}$. W ten sposób Mendelson zapewnił sobie istotny

52 AAN, AL PPS, 305/VII/630, Morawski do Mendelsona, Berlin 16.04.1891, t. 29, k. 169.

${ }^{53}$ AAN, AL PPS, 305/VII/630, List Kurowskiego, 19.07.1891, t. 24, k. 3-4.

54 AAN, AL PPS, 305/VII/630, Mendelson do Sikorskiego, Londyn 1.09.1892, t. 27, k. 579.

55 AAN, AL PPS, 305/VII/630, Mendelson do TSP, grudzień 1892, t. 29, k. 216.

56 AAN, AL PPS, 305/III/262, Listy redakcji „Gazety Robotniczej”.

${ }^{57}$ AAN, AL PPS, 305/VII/630, Morawski do ZZSP, 23.04.1893, t. 29, k. 245.

${ }^{58} \mathrm{~J}$. Żarnowski, op. cit., s. 280.

59 AAN, AL PPS, 305/VII/630, Mendelson do współpracowników, 27.06.1892, t. 27, k. 573-574.

${ }^{60}$ Ibidem; A. Jarosz, Bolesław Antoni Jędrzejowski, [w:] PSB, t. XI, Wrocław-Warszawa-Kraków 1964-1965, s. 239-242. 
wpływ na kształt ideologiczny pisma oraz na samą grupę berlińską - uzależnioną od jego pomocy finansowej. Podsumowując, w okresie od stycznia 1891 r. do września/października 1892 r. za wyjątkiem okresu od lutego do czerwca 1892 r. w Berlinie znajdował się przynajmniej jeden współpracownik Mendelsona. Kolejni emisariusze stanowili solidną podstawę nadzoru nad poczynaniami socjalistów w Berlinie.

Mendelson starał się zapewnić sobie głos decydujący w sprawach niemieckich. Problemem dla niego okazał się być nowy redaktor Gazety - Stanisław Grabski. W listach Mendelsona wyraźnie widać deprecjację Grabskiego oraz chęć odcięcia go od działań w Berlinie. Już 27 czerwca 1892 r. - w kilka tygodni po decyzji o finansowaniu Gazety - Mendelson nosił się z zamiarem wycofania się ze wspierania redakcji, a to za sprawą dziecinnych podejrzewań i insynuacji ${ }^{61}$ ze strony Grabskiego. Na początku września w liście do przyjaciela ponownie Mendelson zaatakował treść Gazety redagowanej przez Grabskiego - treść Gazety staje się coraz to głupszq ${ }^{62}$. Najbardziej napiętym okresem wydaje się być jesień 1892 r. Tuż przed zjazdem założycielskim ZZSP Mendelson wzbraniał się przed obecnością Grabskiego na nim, nazywając go ogółem ${ }^{63}$. Animozje osobiste w działalności Mendelsona odgrywały znaczącą rolę. W tym przypadku jego bezkompromisowość, powodowana przeświadczeniem o byciu centrum polskiego ruchu socjalistycznego, również się objawiła. Mendelson lekceważył zasługi miejscowych socjalistów, nie doceniał ich, dlatego też ponawiał próby kontrolowania redakcji, używając do tego celu kolejnych swoich współpracowników. Grabski był silnym charakterem, cechował się nieprzeciętnym umysłem, dlatego był uważany przez Mendelsona za konkurenta. Momentem krytycznym była próba odsunięcia Grabskiego od redakcji końcem 1892 r. - z Gr. [Grabskim - 00] trzeba zakończyć teraz - jeśli można ${ }^{64}$.

Próby te nie powiodły się mimo przemożnego wpływu grupy londyńskiej. Powodów można upatrywać w zaangażowaniu Grabskiego w sprawę oraz w jego nieprzeciętnych umiejętnościach dialektycznych. Swoje zdolności udowodnił przede wszystkim publikując w Gazecie ${ }^{65}$. Jednocześnie z jego strony nie można doszukać się wrogości czy niechęci do Mendelsona, wręcz przeciwnie - Grabski docenia go jako wyróżniającego się socjalistę ${ }^{66}$. Podobnie całe środowisko berlińskie w obliczu ambicji Mendelsona zachowuje

${ }^{61}$ AAN, AL PPS, 305/VII/630, Mendelson do współpracowników, 27.06.1892, t. 27, k. 573.

${ }^{62}$ AAN, AL PPS, 305/VII/630, Mendelson do Sikorskiego, Londyn 1.09.1892, t. 27, k. 579.

${ }^{63}$ AAN, AL PPS, 305/VII/630, Mendelson do współpracowników, wrzesień 1892, t. 63, k. 156.

${ }^{64}$ AAN, AL PPS, 305/VII/630, Mendelson do Witolda Jodko Narkiewicza, Londyn w grudniu 1892, t. 29, k. 212-213.

65 S. Grabski, op. cit., s. 75-76.

${ }^{66}$ Ibidem, s. 77. 
się niezwykle przyjaźnie - w liście do ZZSP Morawski pisze, że TSP podjęło uchwałę, aby nie lekceważyć zasług Mendelsona i jak dotąd tak i nadal razem wspólnie pracować pomagając sobie wzajemnie ${ }^{67}$. Wydaje się, że najlepszym określeniem związku obu ośrodków jest zależność oparta na pomocy i współpracy, pozbawiona negatywnych następstw nierównej relacji.

Po wydaleniu Jędrzejowskiego z Berlina - co nastąpiło we wrześniu lub październiku $1892 \mathrm{r}^{68}$ - na jego miejsce przybył najprawdopodobniej już w październiku Witold Jodko Narkiewicz. W liście do niego z przełomu 1892 r. i 1893 r. Mendelson denerwuje się na trwające już trzy miesiące poszukiwania źródeł dochodu dla Gazety - personalnie obwiniając Jodkę ${ }^{69}$. Sugeruje to jego obecność przynajmniej od października, a trwała ona zapewne dłużej, gdyż w tym samym liście Mendelson nalega na jego dalszq obecność z różnych względów. Jodko zastąpił zatem Jędrzejowskiego w administracji Gazety. Kontrola poczynań socjalistów polskich w Berlinie trwała zatem nieprzerwanie.

\section{Powstanie PPSzp}

Sytuacja uległa zmianie z chwilą opuszczenia ZZSP przez Mendelsona, co też stało się 28 sierpnia 1893 r. $^{70}$ Socjaliści berlińscy stracili moralnego przywódcę. Naturalnym byłoby zaprzestanie finansowania Gazety, gdyż Mendelson wykładał na ten cel pieniądze ze środków własnych, co jednak się nie stało. ZZSP do Gazety dopłacało od tej chwili po 100 marek miesięcznie ${ }^{71}$. Związek między oboma ośrodkami został zachowany. Niejako ostatnim już posunięciem Mendelsona było doprowadzenie do powstania PPSzp. Według ustaleń Zielińskiego, w Berlinie w dniu zawiązania partii obecny był Jodko ${ }^{72}$. Nie jest jednak pewnym, czy zawiązanie partii powstało z jego inspiracji.

Niezwykle interesujący jest list, który do ZZSP wysłał Morawski w kilka dni po zawiązaniu się PPSzp ${ }^{73}$. W pierwszych zdaniach Morawski pisze:

Niezawodnie ostatni numer Gazety Robotniczej już was doszedł z którego sprawozdania z naszego tu kongresu dowiedzieliście się [pogr. - 0.0.] o naszem zorganizowaniu i wyborze zarządu tej [pogr. - 0.0.] nowej partyi ${ }^{74}$

${ }^{67}$ AAN, AL PPS, 305/VII/630, Morawski do ZZSP, 28.12.1892, t. 29, k. 229-232.

68 A. Jarosz, op. cit., s. 240.

${ }^{69}$ AAN, AL PPS, 305/VII/630, Mendelson do Narkiewicza, grudzień 1892, t. 29, k. 213.

${ }^{70}$ AAN, AL PPS, 305/VII/630, Mendelson do redakcji „Przedświtu”, wrzesień 1893, t. 63, k. 612.

${ }^{71}$ AAN, AL PPS, 305/VII/630, Morawski do ZZSP, 18.09.1893, t. 29, k. 265.

72 V.W. Zieliński, Geneza..., s. 77.

${ }^{73}$ AAN, 305/VII/630, AL PPS, Morawski do ZZSP, 18.09.1893, t. 29, k. 262-265.

${ }^{74}$ Ibidem, k. 262. 
Z powyższego fragmentu można wyciągnąć następujące wnioski: ZZSP miało pojęcie o planach zawiązania nowej partii, jednakże nie było pewności co do terminu tego wydarzenia. Inicjatywę mogli posiadać zarówno przedstawiciele ZZSP w Berlinie, jak i sami socjaliści berlińscy. Na tym tle trudno stwierdzić jak prezentowała się relacja między oboma ośrodkami w okresie po odejściu Mendelsona. Sytuacja stała się mniej klarowna, niż miało to miejsce przed 28 sierpnia.

Można sugerować, że związki personalne między ZZSP a socjalistami polskimi w Berlinie wpłynęły na stanowisko ideowe berlińczyków - a od zbliżenia ideologicznego pozostał krok do zbliżenia organizacyjnego ${ }^{75}$. Zbliżenie to nastąpiło za wiedzą ZZSP, na co wskazuje wyżej cytowany list. Nieznany pozostaje inicjator tego wydarzenia. Wskazanie Mendelsona jest jedynie domysłem, choć co prawda jednym z bardziej prawdopodobnych.

Zbliżenie ideowe, które postępowało od początku współpracy obu ośrodków, nie doprowadziło do oderwania pisma i socjalistów en général od SPD. Za tą sytuacją przemawiały dość istotne przesłanki - PPSzp, nawet ze wsparciem finansowym, personalnym i ideowym od ZZSP nie była w stanie funkcjonować samodzielnie na tak trudnym terenie, jakim był zabór pruski i Niemcy w ogóle. Wsparcie SPD było warunkiem sine qua non dla pomyślnego uwieńczenia jakichkolwiek działań podejmowanych przez polskich socjalistów na tym terenie. Sprzyjającą okolicznością, złudnie sprzyjającą, był brak zaawansowanej agitacji SPD na ziemiach wschodnich Niemiec - w 1890 r. w największym mieście prowincji śląskiej, Wrocławiu, było zaledwie 450 działaczy socjalistycznych ${ }^{76}$. Umożliwiło to wypełnienie pustki politycznej polskim działaczom, co jednak nie było sprawą prostą. SPD miało realne powody do nieangażowania się zanadto w sprawy prowincji wschodnich - miały one charakter głównie rolniczy, w związku z czym propaganda socjalistyczna nie mogła paść tu na podatny grunt. Stąd i TSP więcej miało prenumeratorów „Gazety Robotniczej” w zachodnich Niemczech niż na ziemiach polskich. W takich warunkach współpraca z socjaldemokracją niemiecką była koniecznością.

W tym samym liście ${ }^{77}$, w którym Morawski poinformował zarząd SPD o utworzeniu PPSzp, zawarł też informację o stanie negocjacji z Niemcami. SPD zgodziło się dalej subwencjonować pismo na kwotę 200 marek miesięcznie, co według Morawskiego znaczyło, że wobec tego nie będziemy $w$ stanie

${ }^{75}$ W. Feldman, Dzieje polskiej myśli politycznej 1864-1914, Warszawa 1933, s. 237-238.

${ }^{76}$ V.R. Gelles, Uwagi na temat socjaldemokracji wrocławskiej w latach I wojny światowej, [w:] Klasa robotnicza na Śląsku, t. II, red. F. Hawranek, Opole 1976, s. 40.

77 AAN, AL PPS, 305/VII/630, Morawski do ZZSP, 18.09.1893, t. 29, k. 262-265. 
gazety utrzymać c $^{8}$. Ponadto, działacze polscy zadali zarządowi SPD pytanie, czy można by było zmienić redaktora pisma - Niemcy zgodzili się, a redaktorem został wywodzący się z ZZSP Kazimierz Mokłowski. Tym akcentem zakończyło się formowanie nowej partii socjalistycznej, w dużej mierze zależnej od decyzji socjalistów na emigracji.

\section{Zakończenie}

Powyższe ustalenia precyzują proces powstawania PPSzp, podkreślając elementy jej genezy związane z kontaktami z zagranicą. Zachowana korespondencja polskich działaczy socjalistycznych w Berlinie oraz tych skupionych wokół Stanisława Mendelsona ukazuje wzajemne relacje między oboma grupami. Relacje o charakterze finansowym - „Gazeta Robotnicza” była finansowana przez Mendelsona - personalnym - współpracownicy Mendelsona byli delegowani do Berlina, by pomóc w administracji pisma - oraz ideowym - Mendelson sam pisywał artykuły do „Gazety Robotniczej” ${ }^{\prime 9}$. Niniejsza praca stawiała sobie za cel ponowne rozłożenie akcentów w badaniu ruchu socjalistycznego. To nie sami robotnicy miejscowi stworzyli ruch, oni byli warunkiem sine qua non powstania i rozwoju ruchu, ale prawdziwymi kreatorami była inteligencja zanurzona w ideach socjalistycznych - której przedstawicielem był m.in. Mendelson. Organizacje lokalne socjalistów polskich w Niemczech działały za przyzwoleniem i z pomocą socjaldemokracji niemieckiej, a także ze wsparciem polskich socjalistów poza granicami kraju, skupionymi niedługo potem w ZZSP. Wpływ tej organizacji najpełniej widać w obsadzaniu stanowisk kluczowych dla ośrodka berlińskiego swoimi emisariuszami. Jak zostało powiedziane, socjaliści w Berlinie rdzeń swojej działalności widzieli w agitacji - a agitację tę prowadzono za pomocą „Gazety Robotniczej”, zatem redakcja i administracja pisma były najważniejszymi pozycjami dla grupy Mendelsona, które to pozycje były przez tę grupę obsadzane.

Od stycznia 1891 r. do sierpnia w Berlinie przebywał Wincenty Sikor$\mathrm{ski}^{80}$. Od kwietnia był nękany przez policję - w tym samym czasie Mendelson wysunął propozycję objęcia redakcji przez Ignacego Daszyńskiego ${ }^{81}$. Tenże

78 Ibidem.

79 Np. „Gazeta Robotnicza” 7.03.1891, R. I, nr 10, s. 1 oraz „Gazeta Robotnicza” 14.03.1891, R. I, nr 11, s. 1-2 - Polityka klasowa a polityka narodowa; „Gazeta Robotnicza” 4.04.1891, R. I, nr 14, s. 1-2 - O dwóch świętach; „Gazeta Robotnicza” 18.04.1891, R. I, nr 16, s. 1-2 - Cóż Konstytucja 3 maja przyniosła narodowi; „Gazeta Robotnicza” 13.06.1891, R. I, nr 24, s. 1-2; „Gazeta Robotnicza” 20.06.1891, R. I, nr 25, s. 1-2 - Polityka chudzińskich; „Gazeta Robotnicza” 8.08.1891, R. I, nr 32, s. 1-2 - „Postęp” orędujący i „Orędownik” postępujący; i in.

80 A. Pacholczykowa, op. cit., s. 465.

81 AAN, AL PPS, 305/VII/630, Morawski do Mendelsona, 7.05.1891, t. 29, k. 172. 
był redaktorem od września do lutego 1892 r. Od lutego do czerwca widoczna jest luka w obecności współpracowników Mendelsona w Berlinie, natomiast od czerwca już - na mocy umowy między Mendelsonem a Morawskim ${ }^{82}$ - pojawia się w Berlinie Bolesław Jędrzejowski. Zarządza on administracją do września lub października 1892 r., potem jego miejsce zajmuje Witold Jodko Narkiewicz ${ }^{83}$, który z pewnością obecny jest w Berlinie przynajmniej do stycznia 1893 r., a także bierze udział w kongresie założycielskim PPSzp we wrześniu 1893 r. Z powyższego wyliczenia najdobitniej widać wpływ grupy londyńskiej na kształtowanie się polskiego ruchu socjalistycznego na ziemiach niemieckich - przynajmniej 21 miesięcy z 29 w ogóle od pierwszego wydania „Gazety Robotniczej” do zawiązania PPSzp trwała fizyczna obecność przedstawicieli grupy londyńskiej w Berlinie.

Franciszek Morawski na odwrocie jednego ze swoich listów, datowanego na 16 maja 1893 r., zadał pytanie - Czy Mendelson by coś nie obmyślił ${ }^{84}$ ? Pytanie to obrazuje stan relacji między socjalistami skupionymi wokół Morawskiego a grupą Mendelsona - polscy socjaliści na ziemiach niemieckich i w zaborze pruskim, zależeli od wsparcia socjalistów polskich przebywających na emigracji. Wsparcie, którego udzielano skupionym w Berlinie socjalistom polskim, pod postacią finansową, a także dostarczając redaktorów i administratorów pisma oraz materiału duchownego ${ }^{85}$ okazało się kluczowym dla funkcjonowania polskich ośrodków socjalistycznych na ziemiach niemieckich oraz odegrało istotną rolę w genezie Polskiej Partii Socjalistycznej zaboru pruskiego.

\section{BIBLIOGRAFIA}

\section{Źródła archiwalne}

Archiwum Akt Nowych

Archiwum Londyńskie Polskiej Partii Socjalistycznej.

Zbiór akt osobowych działaczy ruchu robotniczego.

${ }^{82}$ AAN, AL PPS, 305/VII/630, Mendelson do współpracowników, 27.06.1892, t. 27, k. 573.

${ }^{83}$ AAN, AL PPS, 305/VII/630, Mendelson do Witolda Jodko Narkiewicza, grudzień, 1892, t. 29 , k. 212-213.

${ }^{84}$ AAN, AL PPS, 305/VII/630, List Morawskiego, Berlin 16.05.1893, t. 29.

${ }^{85}$ Morawski do socjalisty w Paryżu, Berlin 6 XII 1890, AAN, AL PPS, sygn. 305/VII/630, t. 29, k. 163. 


\section{Prasa}

„Gazeta Robotnicza” 1891-1893.

\section{Źródła drukowane}

Daszyński I., Pamiętniki, red. P. Dembowski, Warszawa 2016.

Grabski S., Pamiętniki, t. 1, red. W. Stankiewicz, Warszawa 1989.

Przybyszewski S., Moi współcześni, red. J. Bartnicka, Warszawa 1959.

\section{Opracowania}

Chlebowczyk J., Procesy narodotwórcze we wschodniej Europie środkowej w dobie kapitalizmu, Warszawa-Kraków 1975.

Feldman W., Dzieje polskiej myśli politycznej 1864-1914, Warszawa 1933.

Gelles R., Uwagi na temat socjaldemokracji wrocławskiej w latach I wojny światowej, [w:] Klasa robotnicza na Śląsku, t. 2, red. F. Hawranek, Opole 1976, s. 37-68.

Glensk J., Procesy prasowe „Gazety Robotniczej” w latach 1891-1901, [w:] Klasa robotnicza na Śląsku, t. V, red. F. Hawranek, Opole 1980, s. 201-234.

Jarosz A., Jędrzejowski Bolesław Antoni, [w:] Polski Słownik Biograficzny, t. 11, Wrocław-Warszawa-Kraków 1964-1965, s. 239-242.

Łabuz M., Polski ruch robotniczy w walce o postęp społeczny /1878-1939/, [w:] 100-lecie polskiego ruchu robotniczego. Odczyty, Katowice 1982.

Łuczko S.Ł., Poezja na łamach „Gazety Robotniczej” (okres berliński 1891-1901), [w:] Klasa robotnicza na Śląsku, t. V, red. F. Hawranek, Opole 1980, s. 235-272.

Myśliński J., Model socjalistycznego periodyku dla robotników w okresie zaborów, [w:] Wokół tradycji kultury robotniczej w Polsce, red. A. Żarnowska, Warszawa 1986, s. 373-305.

Myśliński J., Polska prasa socjalistyczna w okresie zaborów, Warszawa 1982.

Myśliński J., Swobody, fabryk i ziemi! Początki polskiego ruchu socjalistycznego pod zaborami, [w:] Ruch robotniczy na ziemiach polskich, red. S. Sierpowski, Warszawa 2002, s. 7-122.

Pacholczykowa A., Sikorski Wincenty, [w:] Polski Słownik Biograficzny, t. XXXVII, WarszawaKraków 1996-1997, s. 464-468.

Pietraszek E., Etos robotniczy na przełomie epok (1890-1918), [w:] Wokół tradycji kultury robotniczej w Polsce, red. A. Żarnowska, Warszawa 1986, s. 142-173.

Przewłocki J., Kształtowanie się wizji socjalistycznej państwowości w programach i działaniu polskiego ruchu robotniczego, [w:] 100-lecie polskiego ruchu robotniczego. Odczyty, Katowice 1982.

Rzepa K., Socjaliści polscy w Niemczech do 1914 roku, Warszawa 1988.

Zieliński W., Geneza i powstanie Polskiej Partii Socjalistycznej zaboru pruskiego, Katowice 1979.

Zieliński W., Polska partia socjalistyczna zaboru pruskiego 1890/1893-1914, Katowice 1978.

Zieliński W., Rola klasy robotniczej i ruchu robotniczego $w$ walce o wyzwolenie narodowe, [w:] 100-lecie polskiego ruchu robotniczego. Odczyty, Katowice 1982.

Żarnowski J., Robotnicy polscy a Kościół katolicki, [w:] Wokół tradycji kultury robotniczej w Polsce, red. A. Żarnowska, Warszawa 1986, s. 273-293. 


\title{
Oskar Olejnik
}

\section{WOULDN'T MENDELSON WORK SOMETHING OUT? - GENESIS OF POLISH SOCIALIST PARTY OF THE PRUSSIAN PARTITION IN THE LIGHT OF CONNECTIONS WITH LONDON'S SOCIALISTS}

\begin{abstract}
A rticle approaches a try to define relationship between two Polish socialist groupings $\mathrm{A}_{\text {- one created around personality of Stanislaw Mendelson, in London, and the other }}$ one in Berlin from which the Polish Socialist Party in Prussian Partition arose. The existing historiography poses a background for the research. Basing on archives and reminiscence a try was taken to recreate relationship between these two groupings. The analysis points out the existence of financial, personal and ideological relations. These factors make one realize the subjection of Berlin socialists to Mendelson's environment.
\end{abstract}

Keywords: Stanisław Grabski, Witold Jodko Narkiewicz, Stanisław Mendelson, Polish Socialist Party, Polish Socialist Party of the Prussian partition, socialism, SPD, Association of Polish Socialists, Foreign Club of Polish Socialists. 